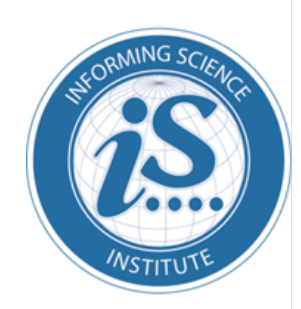

Proceedings of the Informing Science + Information Technology Education Conference

An Official Publication

of the Informing Science Institute

InformingScience.org

InformingScience.org/Publications

June 30 - July 4, 2019, Jerusalem, Israel

\title{
EDUCATIONAL TECHNOLOGY IN IT AND MARKETING EDUCATION - THE EXPERIENCE OF EARLY THAI EDUCATORS [ABSTRACT]
}

Yupawan Vannavanit

Kasetsart University,

fbusywv@ku.ac.th

Bangkok, Thailand

\section{ABSTRACT}

Aim/Purpose

The paper aims to discuss the experience of early Thai educators in adopting Educational Technology in IT and Marketing Education.

Background As the world become increasingly digitized, educators need to keep up through the use of educational technology to effectively increase learning efficiency.

Methodology Conducting an interview

Contribution A hands-on teaching experience in Marketing and IT areas through the use of Educational technology.

Findings

The use of educational technology in Thailand can be found in three main areas namely data transfer, interactive online class and lastly assignment and evaluation. It effectively increases learning efficiency and produce a more proactive learning outcome.

Recommendations for Practitioners

Adopting Educational Technology in IT education can be effectively done through some open-source applications. This mostly benefits those learners who age between 15 and 25 .

Recommendation In choosing group of respondents, technological experience, age groups and for Researchers interest in technology should be carefully taken into account.

Impact on Society The finding aims to provide insights and strategy to develop Thai education system to become more efficient, more memorable and more inspiring through the use of educational technology.

Future Research Any measures and steps that effectively support and redesign educational tools, processes and techniques to support wider and higher education.

Keywords educational technology, IT education, marketing education, Thailand

Accepted by Executive Review by Editor: Eli Cohen | Received: February 9, 2019 | Revised: February 10, 2019 | Accepted: February 12, 2019.

Cite as: Vannavanit, Y. (2019). Educational technology in IT and marketing education - The experience of early Thai educators [Abstract]. Proceedings of the Informing Science and Information Tecbnology Education Conference, Jerusalem, Israel, pp. 459-460. Santa Rosa, CA: Informing Science Institute. https://doi.org/10.28945/4199

(CC BY-NC 4.0) This article is licensed to you under a Creative Commons Attribution-NonCommercial 4.0 International License. When you copy and redistribute this paper in full or in part, you need to provide proper attribution to it to ensure that others can later locate this work (and to ensure that others do not accuse you of plagiarism). You may (and we encourage you to) adapt, remix, transform, and build upon the material for any non-commercial purposes. This license does not permit you to use this material for commercial purposes. 


\section{BIOGRAPHY}

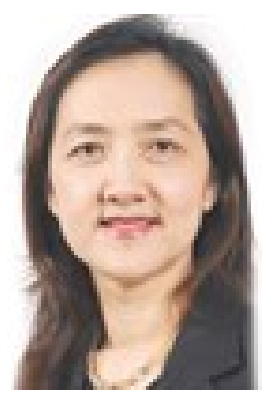

Yupawan Vannavanit has been a marketing professor at Kasetsart University, Bangkok Thailand for more than 30 years. Her research interest includes service marketing, marketing management, information technology and the adoption of technology in education. 